Original Research

\title{
Effects of Deltamethrin and Endosulfan on the Population Growth of Brachionus calyciflorus at Different Algal (Scenedesmus obliquus) Densities
}

\author{
Xiao-Ping $\mathrm{Xu}^{1 *}$, Yi-Long $\mathrm{Xi}^{2}$, Ji-Yuan $\mathrm{Li}^{1}$ \\ ${ }^{1}$ College of Civil Engineering and Architecture, Anhui Polytechnic University, Wuhu, China \\ ${ }^{2}$ Collaborative Innovation Center of Recovery and Reconstruction of Degraded Ecosystem in Wanjiang City Belt, \\ College of Life Sciences, Anhui Normal University, Wuhu, China
}

Received: 9 October 2017

Accepted: 23 December 2017

\begin{abstract}
The chronic effects of deltamethrin and endosulfan on non-target organisms have been investigated several times. However, most of these studies were only performed under certain environmental conditions and ignored the effects of food density. In the present study, the effects of deltamethrin $(0.3,0.6,1.2$, and $2.4 \mathrm{mg} / \mathrm{L})$ and endosulfan $(0.27,0.54,1.08$, and $2.16 \mathrm{mg} / \mathrm{L})$ on the population growth of the rotifer Brachionus calyciflorus were investigated at two densities of Scenedesmus obliquus $\left(1.0 \times 10^{6}\right.$ and $3.0 \times 10^{6}$ cells $/ \mathrm{mL}$ ). Compared with the blank control, high levels of deltamethrin and endosulfan significantly decreased the population growth rate and the maximum population density of B. calyciflorus, suggesting that these two chemicals are toxic to rotifers. In comparison to high algal density, the toxic effects of $2.4 \mathrm{mg} / \mathrm{L}$ deltamethrin and $2.16 \mathrm{mg} / \mathrm{L}$ endosulfan on rotifers were much more obvious at low algal density. The present results show the important role of algal density on influencing the toxicities of deltamethrin and endosulfan to rotifers.
\end{abstract}

Keywords: Brachionus calyciflorus, deltamethrin, endosulfan, algal density, population growth rate, maximal population density

\section{Introduction}

Deltamethrin is a pyrethroid insecticide used extensively in China for the control of mosquitoes and invertebrate pests on a variety of crops and turf grasses.

*e-mail: xuxp1979@126.com
Since deltamethrin showed low toxicity to mammals and birds and limited persistence in soils, it was considered safe and has been increasingly used during the last two decades [1-2].

Endosulfan is a persistent organochlorine pesticide (OCP) used widely to protect important corps. It not only showed high persistence and slow degradation processes in environments, but also caused pesticide poisoning in many countries [3-4]. Although the Chinese government 
has tried to phase out endosulfan, currently endosulfan still has an annual production of 700 tons and mainly is used to control Helicoverpa armigera in field applications of cotton planting [5].

To aquatic organisms, both deltamethrin and endosulfan were revealed to be toxic. For instance, after 14 days of exposure to low concentrations $(0.02 \mu \mathrm{g} / \mathrm{L})$ of deltamethrin, $13 \%$ growth inhibition of the green algae Chlorella vulgaris was observed [6]. Fecundity and hatchability were reduced by $54.12 \%$ and $49.7 \%$, respectively, in zebrafish Danio rerio treated with $0.016 \mu \mathrm{g} / \mathrm{L}$ deltamethrin [7]. The $24 \mathrm{~h}$ and $48 \mathrm{~h}$ EC50 of deltamethrin on the immobilization of Daphnia magna were $8.86-9.40$ and $0.32-0.63 \mu \mathrm{g} / \mathrm{L}$, respectively [8], and at environmentally relevant low concentrations, deltamethrin could have significantly adverse effects on the survival, reproduction, and growth of Ceriodaphnia dubia [9]. Similarly, the population growth rate EC50 of endosulfan on the phytoplankton Chlorophyceae, Cyanophyceae, and Bacillariophyceae varied in the range 4.2 to $15 \mu \mathrm{g} / \mathrm{L}$ [10]. Also, endosulfan was revealed to be moderately toxic to the rotifer Philodina sp. (LC50$24 \mathrm{~h}=1.76 \mathrm{mg} / \mathrm{L}$ ) [11] and Brachionus calyciflorus $($ LC50-24 $\mathrm{h}=5.15 \mathrm{mg} / \mathrm{L})$ [12], but highly toxic to Carassius carassius L (LC50-96 h $=70 \mu \mathrm{g} / \mathrm{L}$ ) [13], the amphipod Hyalella curvispina $(\mathrm{LC} 50-48 \mathrm{~h}=16.4 \mu \mathrm{g} / \mathrm{L}$ ), and fish Cnesterodon decemmaculatus (LC50-48 $\mathrm{h}=1.8$ $\mu \mathrm{g} / \mathrm{L})$ [14]. Most of these studies were conducted under certain environmental conditions. However, in fields the environmental conditions generally change continuously. Aquatic organisms are rarely exposed to any pollutant in isolation, but more often many biotic and abiotic factors act in concert to modify the main toxicant effects. To more accurately evaluate the toxicity of pollutants, it is better to perform the tests under various conditions.

In natural water bodies, the nutrient level varies among seasons and locations. Strong seasonal variations in the phytoplankton abundance (food density) may inevitably affect the toxicity of pesticides to zooplanktons [15]. Rotifers, as the primary consumers in freshwater, provide food for many larval fish and invertebrates and play a significant role in the conversation of organic matter into secondary production and maintaining the stability of the community structure and functions of water ecosystems [16]. B. calyciflorus is a model organism for toxicity evaluation [17], since it is sensitive to changes in water quality [18] and meets the criteria for the ecotoxicological test in environmental risk assessment [19]. Currently, the effects of deltamethrin and endosulfan on B. calyciflorus under gradient food densities have not been reported. In the present study, the quantitative changes in rotifer density and growth rate of the rotifer $B$. calyciflorus in response to different concentrations of deltamethrin and endosulfan at two different algal densities were evaluated. This study aimed to obtain a better understanding of (1) the chronic effects of deltamethrin and endosulfan on the dynamics of B. calyciflorus, and (2) the influences of the algal density on the toxicity of these two pesticides to rotifers. The results would more accurately predict the behavior of deltamethrin and endosulfan in natural water bodies.

\section{Materials and Methods}

Test Organism

B. calyciflorus individuals were originally isolated from Lake Jinghu $\left(31^{\circ} 33^{\prime} \mathrm{N}, 118^{\circ} 37^{\prime} \mathrm{E}\right)$, located at the center of Wuhu city, China. Individuals parthenogenetically reproduced from one strain were continuously cultured in hard synthetic freshwater $(96 \mathrm{mg} \mathrm{NaHCO}, 60 \mathrm{mg}$ $\mathrm{CaSO}_{4}, 60 \mathrm{mg} \mathrm{MgSO}_{4}$, and $4 \mathrm{mg} \mathrm{KCl}$ in $1 \mathrm{~L}$ deionized water) [20] for more than one year. Stock rotifer cultures were kept at $25 \pm 1^{\circ} \mathrm{C}$ under natural light and fed with the single-cell green alga Scenedesmus obliquus. The diet was controlled at a density of approximately $2.0 \times 10^{6}$ cells $/ \mathrm{mL}$.

S. obliquus were grown in a semi-continuous culture using HB-4 medium prepared by dissolving $200 \mathrm{mg}\left(\mathrm{NH}_{4}\right)_{2} \mathrm{SO}_{4}, 15 \mathrm{mg} \mathrm{K} \mathrm{HPO}_{4}, 15 \mathrm{mg} \mathrm{CaCl}$, $80 \mathrm{mg} \mathrm{MgSO}_{4}^{-} 7 \mathrm{H}_{2} \mathrm{O}, 100 \mathrm{mg} \mathrm{NaHCO}_{3}, 25 \mathrm{mg} \mathrm{KCl}$, $0.15 \mathrm{~mL} \mathrm{FeCl}_{3}(1 \%), 1 \mathrm{~mL}$ trace elements solution, and $2 \mathrm{~mL}$ soil extract solution in $1 \mathrm{~L}$ deionized water, and renewed daily at $20 \%$ [21]. Algae at the exponential growth stage were centrifuged and re-suspended in the hard synthetic freshwater. Cell densities of $S$. obliquus suspensions were determined by direct counting using a hemacytometer, and adjusted to the desired concentrations using hard synthetic freshwater. Two algal densities $\left(1.0 \times 10^{6}\right.$ cells $/ \mathrm{mL}$ and $3.0 \times 10^{6}$ cells $\left./ \mathrm{mL}\right)$ were set for the toxicity tests. Two weeks before the commencement of experiments, rotifers were divided into two groups and fed algae daily at $1.0 \times 10^{6} \mathrm{cell} / \mathrm{mL}$ and $3.0 \times 10^{6}$ cells $/ \mathrm{mL}$, respectively.

\section{Chemicals}

Deltamethrin (CAS 52918-63-5, $\mathrm{C}_{22} \mathrm{H}_{19} \mathrm{Br}_{2} \mathrm{NO}_{3}$, purity $\geq 98 \%$ ) and endosulfan (mixture of isomers $\alpha / \beta$ in a ratio 70/30, CAS 115-29-7, $\mathrm{C}_{9} \mathrm{H}_{6} \mathrm{Cl}_{6} \mathrm{O}_{3} \mathrm{~S}$, purity $>99 \%$ ) were both purchased from the Sigma-Aldrich Chemical Co., Ltd. (St. Louis, MO, USA). All other reagents used in the experiment were of analysis grade or higher and were obtained from commercial sources. Deionized water was prepared by a Milli-Q water purification system (Milli-Q Gradient-A 10 , Millipore, USA) at $(25 \pm 1)^{\circ} \mathrm{C}$ and was used in all the experiments. Stock solutions were prepared by dissolving deltamethrin and endosulfan in 100\% acetone, and diluted to the set concentrations using hard synthetic freshwater (final concentration of acetone in each test solution was less than $0.1 \% \mathrm{v} / \mathrm{v}$ ). All the stock solutions were stored at $4^{\circ} \mathrm{C}$.

\section{Population Growth Tests}

Based on preliminary tests, four concentrations were selected for deltamethrin $(0.3,0.6,1.2,2.4 \mathrm{mg} / \mathrm{L})$ and 
endosulfan $(0.27,0.54,1.08,2.16 \mathrm{mg} / \mathrm{L})$. A blank control and an acetone control were also included. Population growth experiments were conducted in $12 \mathrm{~mL}$ test tubes containing $10 \mathrm{~mL}$ solution. In total, 80 tests (10 toxicant concentrations $\times 2$ algal densities $\times 4$ replicates) were carried out. The initial rotifer density was 3 ind./mL of neonates $(<6 \mathrm{~h}$ old $)$. The experiments were conducted at $25 \pm 1^{\circ} \mathrm{C}$ in the dark.

The density of living rotifers in each tube was counted every day. During the first few days, all rotifers were counted. Later, the density was calculated by counting three 1 or $0.5 \mathrm{~mL}$ aliquots. After counting, the rotifers were transferred to fresh tubes containing appropriate culture solutions. After 11 days, rotifer populations in most replicates began to decline. Then the tests were terminated.

\section{Statistical Analyses}

The population growth rate $(r)$ for each test was determined according to the following equation:

$$
r=\left(\ln N_{\mathrm{t}}-\ln N_{0}\right) / t
$$

...where $N_{0}$ is the initial density of rotifers, $N_{\mathrm{t}}$ is the final density, and $t$ is the exposure time [22]. In general, 4-6 data points were chosen from the exponential phase of the population growth curve. Each treatment was tested in four replicates. Mean values and standard errors were calculated from the different replicates [15].

One-way analysis of variance (ANOVA), with treatment as the independent variable and the population growth $(r)$ rates and maximal population density $(K)$ as the dependent variable, followed by the LSD test, was conducted for pair-wise comparisons between treatments and the blank control. From these results, noobserved-effect concentration (NOEC), lowest-observedeffect concentration (LOEC), and median effective concentration (EC50) for each toxicant under two algal densities were determined. The interaction between toxicant concentration and algal density was estimated using two-way analysis of variance (SPSS Version 19.0).

\section{Results and Discussion}

\section{Advantages of Population Growth Study Using the Rotifers}

Population growth and life table demography studies are two important and broadly used methods for evaluating chronic effects of toxicants on zooplanktons [23-25]. The earlier studies reported that the life table parameters of $B$. calyciflorus were influenced by the sublethal levels of deltamethrin and endosulfan $[12,26]$. For example, 2.4-3.0 mg/L deltamethrin and 1.25-3.3 $\mathrm{mg} / \mathrm{L}$ endosulfan significantly decreased the generation time and the intrinsic rate of population increase of B. calyciflorus. Both deltamethrin $(>1.0 \mathrm{mg} / \mathrm{L})$ and endosulfan $(>1.2 \mathrm{mg} / \mathrm{L})$ significantly decreased the net reproductive rate of $B$. calyciflorus. However, life table method does not provide information on the possible adaptation of offspring born under the toxicant treatments chosen for the experiments [24], and the chronic effects of deltamethrin and endosulfan on the population dynamics of $B$. calyciflorus were still unknown.

Compared with the age-specific exposure in life table experiments, the population growth studies could demonstrate the effects of toxicants on full life-cycle of rotifer, i.e., parthenogenesis and sexual reproduction, and individuals of different age groups simultaneously [15]. Therefore, the effects of toxicants on the organism were multi-generational and more comprehensive, and the results would be closer to reality in fields [27]. As early as 1984, the sublethal effects of toxicants on $B$. calyciflorus and B. rubens were studied by analysis of the changes in population growth curves [28]. Several researchers later employed this method to estimate the effects of pesticides, metals, and chemicals on rotifers [29-32]. During the long duration of tests, algal food must be supplemented to avoid the starvation of organisms, and the optimal $S$. obliquus density for survival and reproduction of $B$. calyciflorus was $2.0 \times 10^{6} \mathrm{cell} / \mathrm{mL}[21]$. In the present study, compared to the optimal density, the higher $\left(3.0 \times 10^{6} \mathrm{cell} / \mathrm{mL}\right)$ and lower $\left(1.0 \times 10^{6} \mathrm{cell} / \mathrm{mL}\right)$ levels of $S$. obliquus were chosen to represent the abundance and lack of food resources available for rotifers in nature waterbodies, respectively.

Effects of Deltamethrin and Endosulfan on the Growth Curves of B. calyciflorus Population

In the present study, the growth curves of $B$. calyciflorus population in response to different concentrations of deltamethrin and endosulfan at algal densities of $1.0 \times 10^{6}$ cells $/ \mathrm{mL}$ and $3.0 \times 10^{6}$ cells $/ \mathrm{mL}$ are displayed in Figs 1 and 2, respectively. In controls, the population density of rotifers increased to 160 and $368 \mathrm{ind} . / \mathrm{mL}$ at low and high algal densities, respectively. Exposed to $0.3,0.6$, and $1.2 \mathrm{mg} / \mathrm{L}$ deltamethrin, the population density of rotifers increased to 86,111 , and 55 ind. $/ \mathrm{mL}$ at low algal density, whereas the values were 303,157 , and 94 ind./mL at high algal density. When the deltamethrin was $2.4 \mathrm{mg} / \mathrm{L}$, all rotifers died after 1 and 3 days at low and high algal densities, respectively.

Similarly, exposed to $0.27,0.54$, and $1.08 \mathrm{mg} / \mathrm{L}$ endosulfan, the population density of rotifers increased to 168,163 , and 96 ind./mL at low algal densities, whereas the values were 316,309 , and 283 ind./mL at high algal densities, respectively. In response to $2.16 \mathrm{mg} / \mathrm{L}$ endosulfan, the population cannot be established and all rotifers died after 6 days at low algal density, while the population density of rotifers could increase to $325 \mathrm{ind} . / \mathrm{mL}$ at high algal densities. These results revealed that (1) despite the algal density, the population growth of rotifer were suppressed by increased concentrations of toxicants; and (2) to the given toxicant level, the high algal density is more beneficial to the establishment and growth of the rotifer population than the low algal density. 
Effects of Deltamethrin and Endosulfan on Population Growth Rate and Maximum Population Density of Rotifers

In population growth studies, population growth rate and maximum population density are the two most
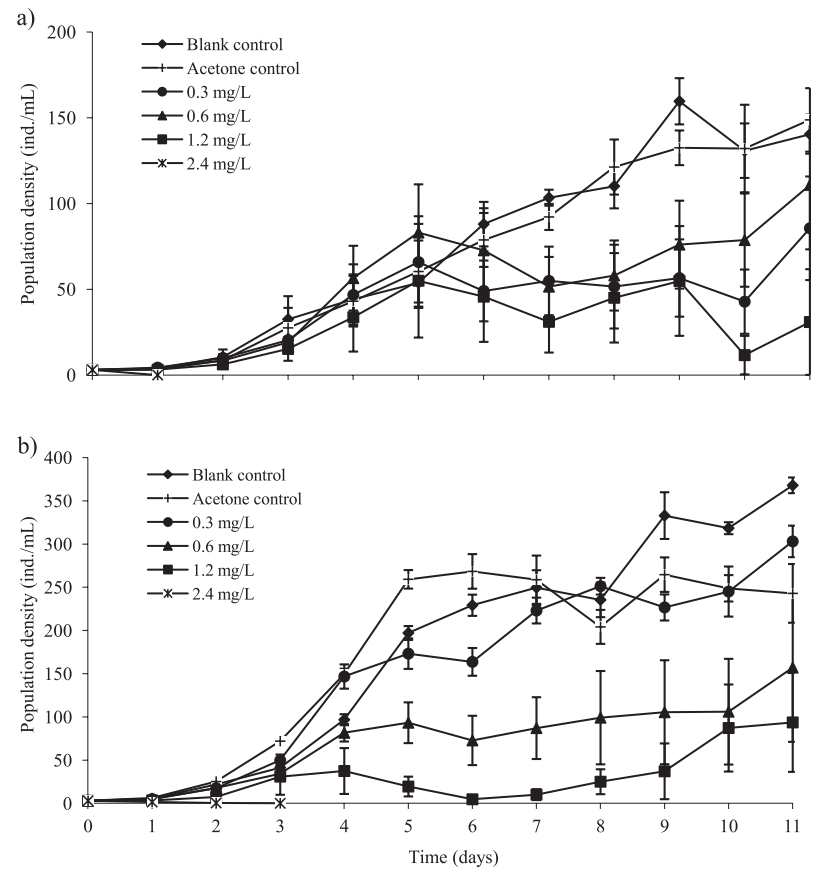

Fig. 1. Population growth of Brachionus calyciflorus exposed to different concentrations of deltamethrin at low $\left(1.0 \times 10^{6}\right.$ cell $/ \mathrm{mL}$, a) and high $\left(3.0 \times 10^{6}\right.$ cells $/ \mathrm{mL}$, b) densities of Scenedesmus obliquus.
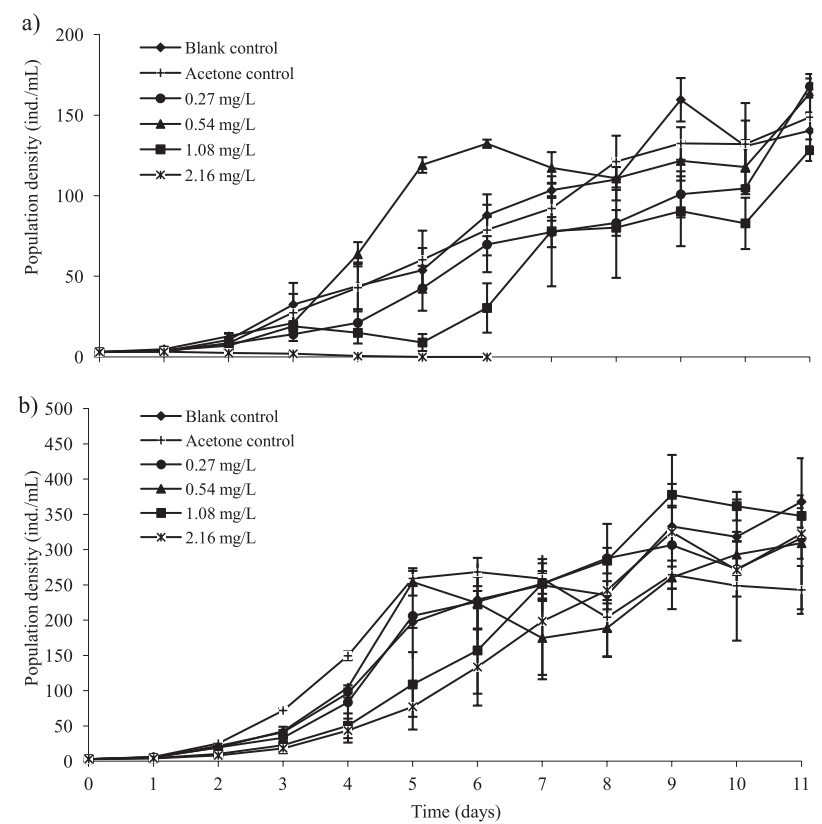

Fig. 2. Population growth of Brachionus calyciflorus exposed to different concentrations of endosulfan at low $\left(1.0 \times 10^{6}\right.$ cell $/ \mathrm{mL}$, a) and high $\left(3.0 \times 10^{6}\right.$ cells $/ \mathrm{mL}$, b $)$ densities of Scenedesmus obliquus. significant bio-indicators representing toxicant stresses These two indicators are the most sensitive to a majority of tested toxicants [33-36]. Generally, toxicants reduce the population growth rate and the maximum population
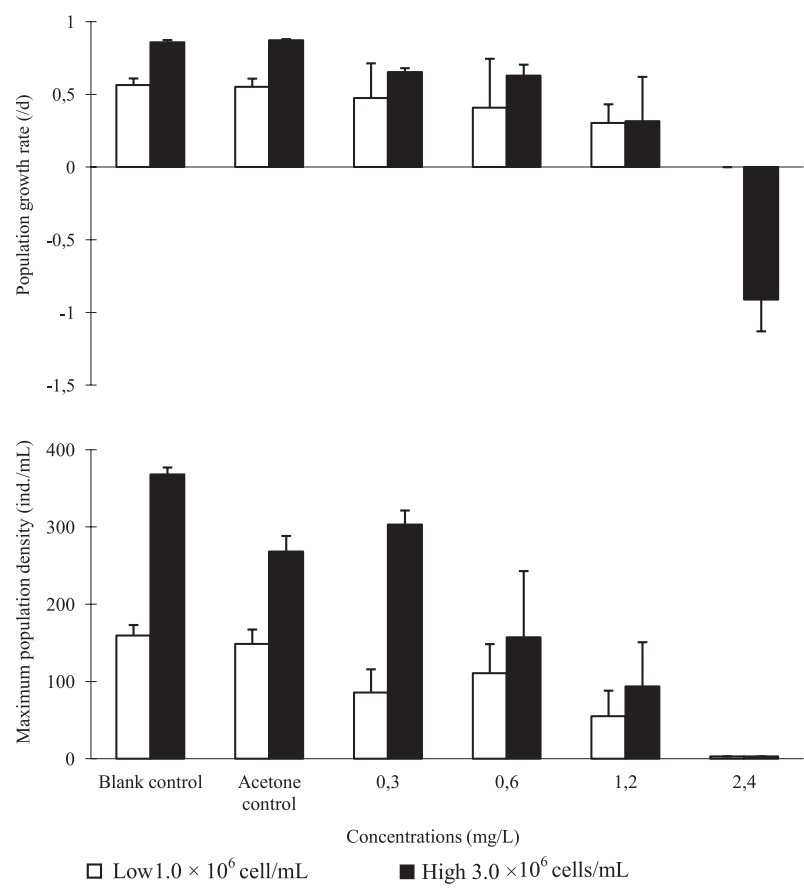

Fig. 3. Population growth rate and the maximal population density of Brachionus calyciflorus in treatments with different concentrations of deltamethrin at low $\left(1.0 \times 10^{6}\right.$ cell $\left./ \mathrm{mL}\right)$ and high $\left(3.0 \times 10^{6}\right.$ cells $\left./ \mathrm{mL}\right)$ densities of Scenedesmus obliquus.
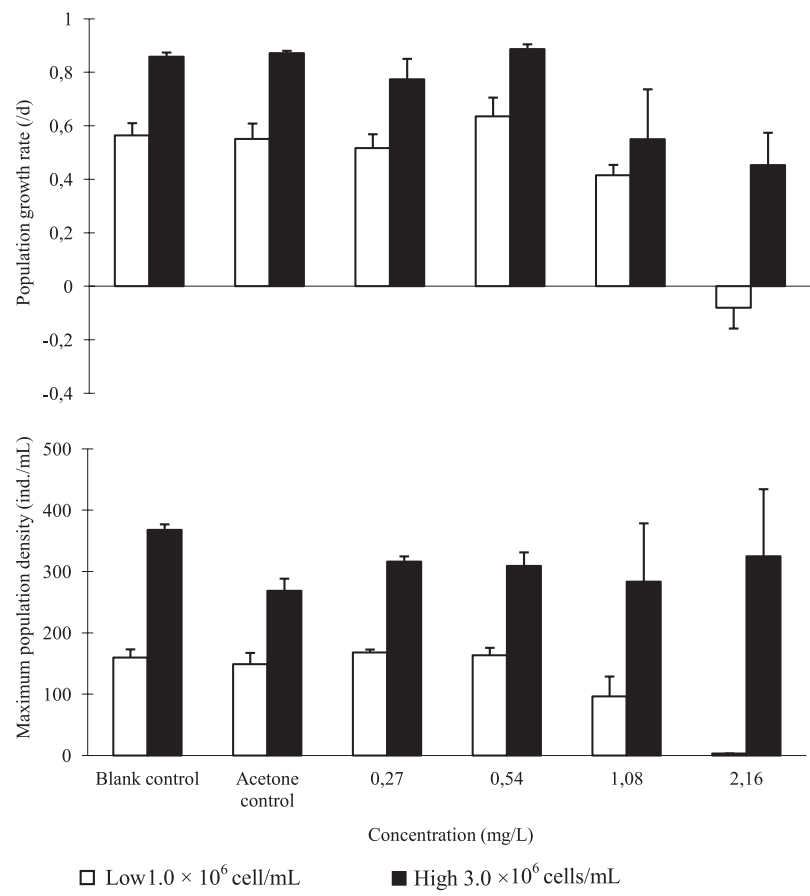

Fig. 4. Population growth rate and maximal population density of Brachionus calyciflorus treated with different concentrations of endosulfan at low $\left(1.0 \times 10^{6} \mathrm{cell} / \mathrm{mL}\right)$ and high $\left(3.0 \times 10^{6}\right.$ cells $\left./ \mathrm{mL}\right)$ densities of Scenedesmus obliquus. 
density of rotifers when subjected to chronic toxicity tests under laboratory conditions, while increases in algal density increased the population growth rate and rotifer maximum density. In the present study, the volume ratio of acetone in the solvent control was the same as that of the highest toxicant concentration group $(<0.1 \% \mathrm{v} / \mathrm{v})$. The results showed that, compared to the blank control, the acetone did not significantly affect the population growth rate and maximum rotifer density $(p>0.05)$, although acetone decreased maximum rotifer density in some degree at the high algal density. Compared with the blank control, 1.2 and $2.4 \mathrm{mg} / \mathrm{L}$ deltamethrin significantly decreased the population growth rate of $B$. calyciflorus by $73.22 \%$ and $202.31 \%$ at high algal density, respectively $(p<0.05) .1 .2$ and $2.4 \mathrm{mg} / \mathrm{L}$ deltamethrin significantly decreased the maximum population density of rotifers by $65.57 \%$ and $98.12 \%$ at low algal density, respectively $(p<0.05)$, and $0.6,1.2$ and $2.4 \mathrm{mg} / \mathrm{L}$ deltamethrin significantly decreased the maximum population density of rotifers by $57.32 \%, 74.56 \%$, and $99.19 \%$ at high algal density, respectively $(p<0.05$; Fig. 3). Compared with low algal density, high algal density significantly increased the maximum population density of rotifers exposed to $0.3 \mathrm{mg} / \mathrm{L}$ deltamethrin $(p<0.01$; Fig. 3).

As shown in Fig 4, compared with the blank control, $2.16 \mathrm{mg} / \mathrm{L}$ endosulfan significantly decreased the population growth rate of rotifers by $114.26 \%$ at low algal density $(p<0.01)$, and 1.08 and $2.16 \mathrm{mg} / \mathrm{L}$ endosulfan significantly decreased the population growth rate of rotifers by $35.88 \%$ and $47.20 \%$ at high algal density, respectively $(p<0.05)$. Compared with the blank control, 1.08 and $2.16 \mathrm{mg} / \mathrm{L}$ endosulfan significantly decreased the maximum population density of rotifers by $39.69 \%$ and $97.98 \%$ at low algal density $(p<0.05)$. Compared with low algal density, high algal density significantly increased the population growth rate of rotifers exposed to $0.27,0.54$, and $2.16 \mathrm{mg} / \mathrm{L}$ endosulfan $(p<0.05)$, and the maximum population density of rotifers 0.27 and $0.54 \mathrm{mg} / \mathrm{L}$ endosulfan $(p<0.01)$. These results also confirmed that the population growth rate and the maximum population density are effective indicators to demonstrating the toxicities of deltamethrin and endosulfan.

In general, the population growth rate $(r)$ is a more sensitive variable to toxicant stress since it considers both the maximum population density $(K)$ and the required duration [34]. However, $K$ was more sensitive to increasing algal density and concentration of DDT and dicofol than $r$ [27], and was regarded as the most sensitive endpoint [28]. In the present study, NOEC, LOEC, and EC50 of $K$ were all lower than $r$ in response to deltamethrin at low and high algal densities, and endosulfan at low algal density, but the reverse was also true for endosulfan at high algal density (Table 1), indicating that the sensitivities of $r$ and $K$ might not only be related to the toxicant species but also to the food level. In addition, compared with endosulfan, the lower EC50 of $r$ and $K$ for deltamethrin at low and high algal densities revealed that deltamethrin was more toxic to the population growth of $B$. calyciflorus than endosulfan (Table 1), which agreed with the results of the acute toxicity tests, i.e., to B. calyciflorus, the LC50-24 h for deltamethrin (4.18 $\mathrm{mg} / \mathrm{L})$ [26] was lower than endosulfan (5.15 mg/L) [12].

\section{Combined Effects of Toxicant Concentration and Algal Density on the Population Growth of B. calyciflorus}

As shown in Table 2, a clear dose-response relationship existed between $r, K$, and the toxicant concentration at two algal densities, except $r$ in deltamethrin at low algaldensity and $K$ in endosulfan at high algal density. Deltamethrin concentration, endosulfan concentration, and algal density significantly affected the population growth rate of $B$. calyciflorus $(p<0.01)$. Deltamethrin concentration and algal density significantly affected the maximal population density of B. calyciflorus $(p<0.01$, Table 3). These results indicated that the population growth of $B$. calyciflorus was sensitive to the algal density and concentration of toxicants in most treatments, which was consistent with the results obtained by $\mathrm{Xu}$ et al. [27]. However, the interaction of toxicant concentration and algal density did not significantly influence the population growth rate and the maximum population density of $B$. calyciflorus $(p>0.05)$, except the algal density $\times$ deltamethrin concentration significantly affected the maximum population density of rotifers $(p<0.05$, Table 3$)$, suggesting that the combined effects of toxicant concentration and algal density on the population growth of $B$. calyciflorus were equally

Table 1. Estimates of chronic toxicity of deltamethrin and endosulfan on the population growth rate $(r)$ and the maximal population density $(K)$ of Brachionus calyciflorus at two Scenedesmus obliquus densities.

\begin{tabular}{|c|c|c|c|c|c|c|c|}
\hline \multirow{2}{*}{ Algal density (cells/mL) } & \multirow{2}{*}{ Parameters } & \multicolumn{3}{|c|}{ Deltamethrin } & \multicolumn{3}{|c|}{ Endosulfan } \\
\hline & & NOEC & LOEC & EC50 & NOEC & LOEC & EC50 \\
\hline \multirow{2}{*}{$1.0 \times 10^{6}$} & $r$ & 1.2 & 2.4 & $>1.2$ & 1.08 & 2.16 & 1.52 \\
\hline & $K$ & 0.6 & 1.2 & 0.79 & 0.54 & 1.08 & 1.44 \\
\hline \multirow{2}{*}{$3.0 \times 10^{6}$} & $r$ & 0.6 & 1.2 & 0.98 & 0.54 & 1.08 & 2.22 \\
\hline & $K$ & 0.3 & 0.6 & 0.65 & 2.16 & $>2.16$ & $>2.16$ \\
\hline
\end{tabular}

NOEC: no-observed effect concentration; LOEC: lowest-observed-effect concentration; EC50: median effective concentration 
Table 2. Relationships between population growth rate $(\mathrm{y}, r)$ and maximal population density $(\mathrm{y}, K)$ of Brachionus calyciflorus and concentrations (x) of deltamethrin and endosulfan at two Scenedesmus obliquus densities.

\begin{tabular}{|c|c|c|c|c|}
\hline Toxicants & Algal density $($ cells $/ \mathrm{mL})$ & Parameters & Regression equation & Significant tests \\
\hline \multirow{3}{*}{ Deltamethrin } & $1.0 \times 10^{6}$ & $\mathrm{~K}$ & $\mathrm{y}=14.46 \mathrm{x}^{2}-93.35 \mathrm{x}+144.68$ & $\mathrm{r}^{2}=0.50, p<0.01$ \\
\cline { 2 - 5 } & $3.0 \times 10^{6}$ & $\mathrm{r}$ & $\mathrm{y}=-0.23 \mathrm{x}^{2}-0.16 \mathrm{x}+0.81$ & $\mathrm{r}^{2}=0.82, p<0.01$ \\
\cline { 2 - 5 } & $3.0 \times 10^{6}$ & $\mathrm{~K}$ & $\mathrm{y}=77.67 \mathrm{x}^{2}-338.76 \mathrm{x}+370.97$ & $\mathrm{r}^{2}=0.71, p<0.01$ \\
\hline \multirow{3}{*}{ Endosulfan } & $1.0 \times 10^{6}$ & $\mathrm{r}$ & $\mathrm{y}=-0.18 \mathrm{x}^{2}+0.10 \mathrm{x}+0.56$ & $\mathrm{r}^{2}=0.84, p<0.01$ \\
\cline { 2 - 6 } & $1.0 \times 10^{6}$ & $\mathrm{~K}$ & $\mathrm{y}=-22.25 \mathrm{x}^{2}-30.59 \mathrm{x}+170.42$ & $\mathrm{r}^{2}=0.80, p<0.01$ \\
\cline { 2 - 6 } & $3.0 \times 10^{6}$ & $\mathrm{r}$ & $\mathrm{y}=0.02 \mathrm{x}^{2}-0.26 \mathrm{x}+0.89$ & $\mathrm{r}^{2}=0.38, p<0.05$ \\
\hline
\end{tabular}

Table 3. Two-way analysis of variance of population growth rate and maximal population density of Brachionus calyciflorus treated with different concentrations of toxicants at two Scenedesmus obliquus densities.

\begin{tabular}{|c|c|c|c|c|}
\hline Source & SS & DF & MS & $\mathrm{F}$ \\
\hline \multicolumn{5}{|c|}{ Population growth rate } \\
\hline Deltamethrin concentration & 8.107 & 4 & 2.027 & $13.539^{* *}$ \\
\hline Algal density & 0.248 & 1 & 0.248 & $1.654 \mathrm{~ns}$ \\
\hline Deltamethrin concentration $\times$ Algal density & 0.085 & 3 & 0.028 & $0.190 \mathrm{~ns}$ \\
\hline Error & 4.042 & 27 & 0.150 & \\
\hline Endosulfan concentration & 1.728 & 4 & 0.432 & $14.746^{* *}$ \\
\hline Algal density & 0.864 & 1 & 0.864 & $29.495^{* *}$ \\
\hline Endosulfan concentration $\times$ Algal density & 0.172 & 4 & 0.043 & $1.467 \mathrm{~ns}$ \\
\hline Error & 0.879 & 30 & 0.029 & \\
\hline \multicolumn{5}{|c|}{ Maximal population density } \\
\hline Deltamethrin concentration & 323869.615 & 4 & 80967.404 & $12.416^{* *}$ \\
\hline Algal density & 130394.478 & 1 & 130394.478 & $19.995^{* *}$ \\
\hline Deltamethrin concentration $\times$ Algal density & 58273.158 & 3 & 19424.386 & $2.979^{*}$ \\
\hline Error & 176077.252 & 27 & 6521.380 & \\
\hline Endosulfan concentration & 53588.494 & 4 & 13397.123 & $1.451 \mathrm{~ns}$ \\
\hline Algal density & 409111.302 & 1 & 409111.302 & $44.300^{* *}$ \\
\hline Endosulfan concentration $\times$ Algal density & 41307.541 & 4 & 10326.885 & $1.118 \mathrm{~ns}$ \\
\hline Error & 277052.893 & 30 & 9235.096 & \\
\hline
\end{tabular}

SS: Sum of Squares; DF: Degrees of Freedom; MS: Mean Square; F: F-value; ${ }^{*}$ Significant $(P<0.05),{ }^{* *}$ highly significant $(P<0.01)$, ns: non-significant $(P>0.05)$

profound. In the present study, the solution and the algae were daily renewed and the problem of bioaccumulation of deltamethrin and endosulfan in the alga might be negligible, although the fact that the toxicant could be degraded or accumulated in the algal cells has been confirmed [37]. The action model of deltamethrin and endosulfan to $S$. obliquus deserves further investigation.

Furthermore, the present results showed that along with the increasing toxicant concentration, the interactions between toxicant concentration and algal density were intensifying. For example, the adverse effects of $2.4 \mathrm{mg} / \mathrm{L}$ deltamethrin and $2.16 \mathrm{mg} / \mathrm{L}$ endosulfan on rotifers were much more severe at low algal density, in comparison to high algal density. Several reasons could be quoted to explain these phenomena. Firstly, the availability of food resources was relatively greater at high algal density, which would provide more energy for rotifers to resist toxicant stress [33]. Secondly, at high algal density, more algal cells existed in the culture media, which would dilute the toxicant concentration in each algal cell. When rotifers ate the same amount of alga, the total intake amount of toxicants was reduced. Thirdly, the maximal population density of rotifers was significantly higher at higher algal density, in comparison 
to low algal density. The growth dilution would decrease the body burden of toxicants in rotifer individuals and thus minimize their toxicity on rotifer populations. These speculations, however, still deserve further research with a wider range of toxicant concentrations.

The organisms in aquatic environments are often faced with a multitude of stressors of both natural and anthropogenic origin. It is well known that planktonic rotifers, including Brachionus spp., dwelling in natural habitats are generally sensitive to the changes of water quality [38-40]. Therefore, natural stressors are particularly important to be considered when investigating the interaction with manmade toxicants [18]. Thus, apart from the food resources, water temperature and salinity as well as the other environmental factors in the ambient water inevitably interact with toxicants, which thereby cause changes in the tolerance capacity of rotifers [4142]. Therefore, the combined effects of multiple factors associated with the toxicities of deltamethrin and endosulfan on rotifers deserve further examination.

\section{Conclusions}

The present results show that deltamethrin and endosulfan had significant effects on the population dynamics of $B$. calyciflorus at two algal densities, and increased concentrations of toxicants decreased the population growth rate and the maximum population density of rotifers. Algal density played an important role in influencing the toxicities of deltamethrin and endosulfan to $B$. calyciflorus, and an increase in algal density reduced the toxicity of toxicants.

In China, there has been an increase in the use of different pesticides by the agricultural sector, including deltamethrin and endosulfan. Aquatic environments are usually the final depository for these pesticides, which pose some of the adverse effects because of their influence on both target and non-target organisms, such as rotifers. It is well known that algal density in aquatic environments varies considerably through seasons. According to the present results, the effects of deltamethrin and endosulfan on $B$. calyciflorus could be intense when the primary production of the pond is lowered. Thus, it is quite possible that deltamethrin and endosulfan might prove hazardous to $B$. calyciflorus at much lower concentrations in natural waters than those established by laboratory tests alone. In other words, strong seasonal variations in the algal densities in natural waters can be expected to result in differential susceptibility of $B$. calyciflorus to deltamethrin and endosulfan.

\section{Acknowledgements}

We thank Dr. Gen Zhang from the Shenzhen Nobel Science and Technology Service Co., Ltd. for the comments and language corrections. This work was supported by the Anhui Province Natural Science Foundation (1808085ME133, 1808085QE146), Excellent Youth Talent Support Project of High Education of Anhui Province (gxyq2018023), and the Key Project of Natural Science Research in Anhui Province (KJ2016A063).

\section{Conflict of Interest}

The authors declare no conflict of interest.

\section{References}

1. OLIVEIRA C., ALMEIDA J., GUILHERMINO L., SOARES A.M.V.M., GRAVATO C. Acute effects of deltamethrin on swimming velocity and biomarkers of the common prawn Palaemon serratus. Aquat. Toxicol. 124, 209, 2012.

2. KHAN H.A.A., AKRAM W., HAIDER M.S. Genetics and mechanism of resistance to deltamethrin in the house fly, Musca domestica, L. from Pakistan. Ecotoxicology 24, 1, 2015.

3. KATHPAL T.S., SINGH A., DHANKHAR J.S., SINGH G. Fate of endosulfan in Cotton Soil under Sub-tropical Conditions of Northern India. Pest Manag. Sci. 50, 21, 2015.

4. ASTOVIZA M.J., NATALIA C., CLAUDIO B., MIGOYA M.C., COLOMBO J.C. Massive airborne endosulfan inputs related to intensive agriculture in Argentina's Pampa. Chemosphere 144, 1459, 2016.

5. YI S., LIU J.G., JIN J., ZHU J. Assessment of the occupational and environmental risks of hexabromocyclododecane (HBCD) in China. Chemosphere 150, 431, 2016.

6. LUTNICKA H., FOCHTMAN P., BOJARSKI B., LUDWIKOWSKA A., FORMICKI G. The influence of low concentration of cypermethrin and deltamethrin on phyto- and zooplankton of surface waters. Folia Biol. 62, 251, 2014.

7. SHARMA D.K., ANSARI B.A. Effect of the synthetic pyrethroid deltamethrin and the neem-based pesticide achook on the reproductive ability of zebrafish, Danio rerio (Cyprinidae). Arch. Pol. Fish. 18, 157, 2010.

8. TOUMI H., BOUMAIZA M., MILLET M., RADETSKI C.M., FELTEN V., FOUQUE C., FÉRARD J.F. Effects of deltamethrin (pyrethroid insecticide) on growth, reproduction, embryonic development and sex differentiation in two strains of Daphnia magna (Crustacea, Cladocera). Sci. Total Environ. 458, 47, 2013.

9. SHEN M.F., KUMAR A., DING S.Y., GROCKE S. Comparative study on the toxicity of pyrethroids, $\alpha$-cypermethrin and deltamethrin to Ceriodaphnia dubia. Ecotoxicol. Environ. Saf. 78, 9, 2012.

10. NAIK A.A., WANGANEO A. Occurrence of some pesticides in Bhoj wetland Bhopal and their effect on phytoplankton community: An ecological perspective. J. Toxicol. Environ. Health Sci. 6, 170, 2014.

11. ALLINSON G., HAGEN T., SALZMAN S., WIGHTWICK A., NUGEGODA D. Effect of increasing salinity on the acute toxicity of a commercial endosulfan formulation to the bdelloid rotifer. Toxicol. Environ. Chem. 93, 722, 2011. 
12. FERNANDEZ-CASALDERREY A., FERRANDO M.D., ANDREU-MOLINER E. Demographic parameters of Brachionus calyciflorus, Pallas (Rotifers) exposed to sublethal endosulfan concentrations. Hydrobiologia 226, 103, 1991.

13. DAR S.A., YOUSUF A.R., BALKHI M.U., GANAI F.A., BHAT F.A. Assessment of endosulfan induced genotoxicity and mutagenicity manifested by oxidative stress pathways in freshwater cyprinid fish crucian carp (Carassius carassius L.). Chemosphere 120, 273, 2015.

14. MUGNI H., PARACAMPO A., DEMETRIO P., SCALISE A., SOLÍS M., FANELLI S., BONETTO C. Acute toxicity of endosulfan to the non-target organisms Hyalella curvispina, and Cnesterodon decemmaculatus. Bull. Environ. Contam. Toxicol. 95, 363, 2015.

15. GAMA-FLORES J.L., SARMA S.S.S., NANDINI S. Acute and chronic toxicity of the pesticide methyl parathion to the rotifer Brachionus angularis (Rotifera) at different algal (Chlorella vulgaris) food densities. Aquat. Ecol. 38, 27, 2004.

16. DIAS J.D., BONECKER C.C., MIRACLE M.R. The rotifer community and its functional role in lakes of a neotropical floodplain. Int. Rev. Hydroboil. 99, 72, 2014.

17. ASTM. Standard guide for acute toxicity test with the rotifer Brachionus. American Society for Testing and Materials. Philadelphia PA, USA, E1440, 2004.

18. DAHMS H.U., HAGIWARA A., LEE J.S. Ecotoxicology, ecophysiology, and mechanistic studies with rotifers. Aquat. Toxicol. 101, 1, 2011.

19. BREITHOLTZ M., RUDEN C., HANSSON C.O., BENGTSSON B.E. Ten challenges for improved exotoxicological testing in environmental risk assessment. Ecotoxicol. Environ. Saf. 63, 324, 2006.

20. USEPA. In: Peltier WH, Weber CI (Eds.) Methods for measuring the acute toxicity of effluents to freshwater and marine organisms. Washington DC: US. Environment Protection Agency, EPA/600/4e85/013, 1985.

21. ZHAO L.L., XI Y.L., HUANG L., ZHA C.W. Effects of three phthalate esters on the life-table demography of freshwater rotifer Brachionus calyciflorus Pallas. Aquat. Ecol. 43, 395, 2009.

22. KREBS C.J. Ecology. The experimental analysis of distribution and abundance, 3rd ed. Harper and Row, NY, USA, 398 pp, 1985.

23. ZHANG L.L., NIU J.F., LI Y., WANG Y.J., SUN D. Evaluating the sub-lethal toxicity of PFOS and PFOA using rotifer Brachionus calyciflorus. Environ. Pollut. 180, 34, 2013.

24. SHA J.J., YOU W., CHEN H.M., WANG M., WANG H., LI X.H., QI L., TANG X.X. Using population demographic parameters to assess impacts of two polybrominated diphenyl ethers (BDE-47, BDE-209) on the rotifer Brachionus plicatilis. Ecotoxicol. Environ. Saf. 119, 106, 2015.

25. HUANG Y., LI L., LIU J., LIU J.G., LIN W. Botanical pesticides as potential rotifer-control agents in microalgal mass culture. Algal Res. 4, 62, 2014.

26. XU X.P., XI Y.L., CHU Z.X., CHEN F. Effect of deltamethrin on experimental population dynamics of freshwater rotifers Brachionus calyciflorus. Acta Zool. Sin. 51, 251, 2005 [In Chinese].

27. XU X.P., XI Y.L., CHU Z.X. Effects of DDT and dicofol on population growth of Brachionus calyciflorus Pallas
(Rotifera) under different algal (Scenedesmus obliquus) densities. J. Environ. Biol. 35, 907, 2014.

28. HALBACH U. Population dynamics of rotifers and its consequences for ecotoxicology. Hydrobiologia 109, 79, 1984.

29. GUO R.X., REN X.K., REN H.Q. Effects of dimethoate on rotifer Brachionus calyciflorus using multigeneration toxicity tests. J. Environ. Sci. Health. Part B 47, 883, 2012.

30. ARNOLD W.R., DIAMOND R.L., SMITH D.S. Acute and chronic toxicity of copper to the euryhaline rotifer, Brachionus plicatilis ("L" strain). Arch. Environ. Contam. Toxicol. 60, 250, 2011.

31. WANG Y.J., NIU J.F., ZHANG L.L., SHI J.H. Toxicity assessment of perfluorinated carboxylic acids (PFCAs) towards the rotifer Brachionus calyciflorus. Sci. Total Environ. 491, 266, 2014.

32. ZHANG L.L., NIU J.F., WANG Y.J. Full life-cycle toxicity assessment on triclosan using rotifer Brachionus calyciflorus. Ecotoxicol. Environ. Saf. 127, 30, 2016.

33. LUNA-ANDRADE A., AGUILAR-DURAN R., NANDINI S., SARMA S.S.S. Combined effects of copper and microalgal (Tetraselmis suecica) concentrations on the population growth of Brachionus plicatilis Müller (Rotifera). Water, Air, Soil Pollut. 141, 143, 2002.

34. MARCIAL H.S., HAGIWARA A., SNELL T.W. Effect of some pesticides on reproduction of rotifer Brachionus plicatilis Müller. Hydrobiologia 546, 569, 2005.

35. SARMA S.S.S., CORRAL-JÁCQUEZ F.I., NANDINI S., BRENA-BUSTAMANTE P. Population level indicators of stress: Effects of two heavy metals (copper and mercury) on the growth of Lecane quadridentata (Ehrenberg, 1830) (Rotifera: Lecanidae). J. Environ. Sci. Health. Part A 45, 32, 2010.

36. FARHADIAN O., DAGHIGHI L., DORCHE E.E. Effects of microalgae and alfalfa meal on population growth and production of a freshwater rotifer, Euchlanis dilatata (Rotifera: Mongononta). J. World Aquacult. Soc. 44, 86, 2013.

37. JIN Z.P., LUO K., ZHANG S., ZHENG Q., YANG H. Bioaccumulation and catabolism of prometryne in green algae. Chemosphere 87, 278, 2012.

38. DEMETRAKI-PALEOLOG A. Studies on sustainability of planktonic rotifer assemblages in select national park ponds and wetland reservoirs. Pol. J. Environ. Stud. 23, 51, 2014.

39. BIELANSKA-GRAJNER I., CUDAK A. Effects of salinity on species diversity of rotifers in anthropogenic water bodies. Pol. J. Environ. Stud. 23, 27, 2014.

40. WEN X.L., ZHAI P., FENG R.N., YANG R.J., XI Y.L. Comparative analysis of the spatio-temporal dynamics of rotifer community structure based on taxonomic indices and functional groups in two subtropical lakes. Sci. Rep. 7, 578, 2017.

41. GAMA-FLORES J.L., SARMA S.S.S., NANDINI S. Interaction among copper toxicity, temperature and salinity on the population dynamics of Brachionus rotundiformis, (Rotifera). Hydrobiologia 546, 559, 2005.

42. ARNOLD W.R., DIAMOND R.L., SMITH D.S. The effects of salinity, $\mathrm{pH}$, and dissolved organic matter on acute copper toxicity to the rotifer, Brachionus plicatilis ("L" strain). Arch. Environ. Contam. Toxicol. 59, 225, 2010. 